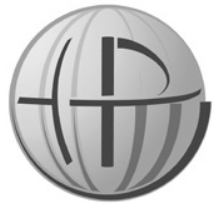

Horyzonty Polityki 2020, Vol. 11, No 35

OPEN ACCESS

\section{Jacek Piotrowski}

http://orcid.org/0000-0001-5227-9945

Uniwersytet Wrocławski

Instytut Historyczny jacek.piotrowski@uwr.edu.pl

DOI: 10.35765/HP.1865

\title{
Krytyka władzy autorytarnej w Polsce 1926-1939 na łamach pism Stanisława Strońskiego
}

\section{Streszczenie}

CEL NA U KOWY: Analiza pism Stanisława Strońskiego zawierających krytykę władzy autorytarnej w Polsce przedwrześniowej. Wskazanie silnych i słabych stron tej krytyki na podstawie konkretnych przykładów. Konfrontacja krytyki władzy autorytarnej z dostępną literaturą na ten temat. Krytyczna ocena stawianych zarzutów natury stricte publicystycznej.

PROBLEM I METODY BADAWCZE: Jakie elementy krytyki władzy autorytarnej Stroński uznawał za najważniejsze? Które z nich mają charakter doraźny (charakterystyczny jedynie dla opisywanej epoki), a które ewentualnie możemy uznać na uniwersalne/ponadczasowe? Zestawienie argumentów publicystycznych z obu stron politycznego sporu, konfrontacja sformułowanych zarzutów z literaturą przedmiotu oraz dostępnymi źródłami historycznymi, wnioskowanie na podstawie krytycznej analizy wykorzystanych materiałów.

PROCES WYWODU: W tekście dokonuję zestawienia ostrej krytyki publicystycznej z obiektywną literaturą przedmiotu w postaci licznych opracowań naukowych, wspomnień i dzienników wymienionych przez autora osób, wreszcie także źródeł historycznych jak: Protokoły posiedzeń Rady Ministrów, Dzienniki czynności prezydenta itp. Poprzez krytyczną analizę sformułowanych zarzutów w różnych obszarach życia publicznego staramy się doprecyzować i ocenić zasadność sformułowanych uwag krytycznych, potwierdzić je lub odrzucić - zgodnie ze sztuką krytyki źródeł, zarówno 
w odniesieniu do ówczesnej sytuacji wewnętrznej państwa polskiego, jak i jego polityki zagranicznej.

WYNIKI ANALIZY NAUKOWEJ: Wśród obszarów krytyki władzy autorytarnej możemy z całą pewnością wskazać dziedziny charakterystyczne dla określonej epoki historycznej (np. przejęcia władzy drogą zbrojnego zamachu stanu), jak również dostrzegamy pewne elementy, które mogą mieć charakter ponadczasowy, a wskazują niekiedy na autorytarny model sprawowania władzy.

WNIOSKI, INNOWACJE, REKOMENDACJE: Zasadniczą rekomendacją jest zwrócenie uwagi na istotne źródło historyczne, jakim są pisma Stanisława Strońskiego, dotąd rzadko wykorzystywane w dyskusjach naukowych toczonych przez politologów.

\title{
SŁowA KLuczowe:
}

władza autorytarna, krytyka, Stanisław Stroński, publicystyka polityczna

\author{
Abstract \\ CRITICISM OF THE AUTHORITARIAN \\ GOVERNMENT IN POLAND IN 1926-1939 \\ BY STANISŁAW STROŃSKI
}

RESEARCH OBJECTIVE: Analysis of the writings by Stanisław Stroński critical about authoritarian government in Poland under Piłsudski's rule. Indicating its strong and weak points on the basis of specific examples. Confrontation of the authoritarian government criticism with the available literature. Critical evaluation of publicist accusations.

RESEARCH PROBLEM AND METHODS: What elements of authoritarian government criticism did Stroński emphasize? Which of them are of temporary (limited to the current era), and which of universal character? Comparison of publicist arguments of both sides of political debate. Confrontation of the formed accusations with relevant literature and available historical sources. Formulating conclusions based on critical analysis of the sources.

THE PROCESS OF ARGUMENTATION: Analysis of internal and external policy of the contemporary government based on monographic works, autobiographies, diaries of politicians mentioned by the Author; and historical sources e.g.: Protokoły posiedzeń Rady Ministrów, Dzienniki czynności prezydenta etc. 
Specification and evaluation of critical remarks validity (confirmation or rejection) - according to the source criticism art.

RESEARCH RESULTS: The areas of authoritarian government criticism include those referring to particular historical era (e.g. seizing power by coup d'état ) and some presumably universal elements indicating quasi authoritarian governing model

CONCLUSIONS, RECOMMENDATIONS AND INNOVATIONS: The principal recommendation is pointing at Stanisław Stroński writings the significant historical source, rarely used by political scientists in scientific discourse.

\section{KeYwORDS:}

authoritarian government, criticism, Stanisław Stroński, political publicism

\section{WSTĘP}

Po klęsce wrześniowej i gruntownej przebudowie rządu na uchodźstwie w Paryżu, jesienią 1939 roku wielu publicystów podjęło krytykę wcześniejszych rządów autorytarnych w Polsce. Nikt jednak nie miał ku temu większych możliwości niż bohater tego tekstu, który w nowym rządzie pełnił funkcję wicepremiera oraz ministra informacji (Rojek,1994, s. 1). Z racji kierowania polską propagandą miał dostęp do wielu cennych materiałów. Przede wszystkim jednak dysponował dużą wiedzą jako jeden z czołowych parlamentarzystów opozycji narodowo-chadeckiej w okresie przedwrześniowym. Warto przypomnieć, że był profesorem UJ, wybitnym publicystą (przez pewien czas także współwłaścicielem „Rzeczypospolitej”), a przy tym także działaczem politycznym dużego kalibru (Faryś, 1990). Jego krytyczne wobec piłsudczyków wystąpienia publiczne oraz artykuły prasowe były wcześniej znane w kraju i nie bez podstaw uchodził za jednego z najbardziej konsekwentnych przeciwników politycznych marszałka Józefa Piłsudskiego i jego obozu. Na co zwracał szczególną uwagę? Czy sformułowana przez niego krytyka miała walory uniwersalne/ ponadczasowe?

Stanisław Stroński był człowiekiem dużej wiedzy humanistycznej, nadto gorącym zwolennikiem demokracji parlamentarnej i ścisłego 
sojuszu z Francją (z zawodu profesor romanistyki). Jednocześnie był cywilem „do szpiku kości”. Typowy galicyjski inteligent, który dla weteranów legionowych - najczęściej ludzi czynu, na ogół dalekich od prowadzenia intelektualnych rozważań, a stanowiących bezpośrednie zaplecze rządów autorytarnych - był człowiekiem nieomal z innej planety, co najmniej podejrzanym „intelektualistą".

Jako polityk odgrywał na uchodźstwie istotną rolę u boku gen. Władysława Sikorskiego. Prowadził kluczowe rozmowy z prezydentem Władysławem Raczkiewiczem, które doprowadziły do powstania nowego rządu (Piotrowski, 2004, s. 51). Początkowo rozważano powołanie go na premiera, jednak ostatecznie został nim zaprzyjaźniony „,jenerał”. Stroński pozostał jednym z czołowych współpracowników szefa rządu. Jakkolwiek po kilku latach został z gabinetu odwołany, a jego miejsce zajął prof. Stanisław Kot (Rutkowski, 2000, s. 329), zawsze bronił polityki Sikorskiego i ostro krytykował „przedwrześniowe stosunki" w Polsce. Jako szczery demokrata wielokrotnie zwracał uwagę na słabe strony rządów autorytarnych, które miały miejsce w Polsce po zamachu majowym 1926 roku. Jego krytyka miała charakter pryncypialny, choć nie dotyczyła tylko kwestii ustrojowych czy merytorycznych. Niekiedy dotykała także kwestii personalnych, kiedy zarzucał adwersarzom m.in. intelektualne braki. Niemniej, wskazując na słabe strony rządów autorytarnych, na ogół starał się być rzeczowy, podając konkretne argumenty przeciw tej formie sprawowania władzy.

\section{POLITYKA WEWNĘTRZNA}

Na długiej liście krytycznych ocen jako pierwszy argument pojawia się oczywiście sposób „pochwycenia władzy” drogą zamachu stanu. Postępowanie piłsudczyków oceniał mocno krytycznie jako podważenie demokratycznych struktur państwa i odrzucenie wartości, na których odbudowano Drugą Rzeczpospolitą. W jego ocenie była to zbrodnia wobec wszystkich rodaków i państwa, które w ten sposób przestało być wartością wspólną ogółu obywateli. Zamachowcy przez cały czas swych rządów nie zamierzali z nikim dzielić się władzą i czuli się niemal właścicielami państwa, którym kierowali. Stroński pisał: „Był to, bezprzykładny w ciągu całych naszych dziejów, okres 
wybujałej pychy jednego człowieka i jednej koło niego grupki, rzucającej przez 13 lat dzień w dzień wyzwanie całemu społeczeństwu i chełpiącej się swą... radosną twórczością" (Stroński, 2007, s. 50).

Stroński wielokrotnie podkreślał, że przejęcie władzy siłą w trybie pozaprawnym ugruntowało poza Polską opinię, iż w Warszawie rządy mają charakter dyktatorski. Jego zdaniem - jako zwolennika rządów parlamentarnych - niszczyło to dobrą opinię na temat Rzeczypospolitej na arenie międzynarodowej. Podobnie zresztą, jak wszelkie łamanie prawa. Dla Strońskiego - czułego na opinię międzynarodową - niewybaczalny był fakt, że w ten sposób potwierdzano zakorzeniony od XVIII wieku stereotyp, jakoby Polacy nie potrafili rządzić swym krajem. W jego opinii czynniki rządzące stały się zamiast obrońcami prawa i porządku konstytucyjnego - jego burzycielami. Twierdził, że na oczach obywateli dokonało się istotne, ale wyraźnie niekorzystne przewartościowanie. Pojęcie służby państwu stopniowo zostało wyparte przez najwyżej cenioną lojalną służbę obozowi rządzącemu. Stroński konsekwentnie podkreślał, że wierność obozowi politycznemu, w tym przypadku tzw. sanacji, nie jest równoznaczna z zasługami rangi państwowej.

Wskazywał przy tym konkretne przykłady tego typu „wynaturzeń". Jednym z nich była podporządkowana interesom obozu rządzącego policja. Podkreślał przy tym, że wcześniej stała ona na wysokim poziomie merytorycznym i nie była uzależniona od żadnej siły politycznej. Była jedną z najlepszych struktur odbudowanego państwa, wzorowaną na policji brytyjskiej. Bazując na własnych doświadczeniach, byłświadkiem brutalnych pobić polityków opozycji po zamachu majowym (Sioma, 2005, s. 131), sprawców których nawet nie próbowano ścigać, zwracał uwagę na wynaturzenia instytucji powołanej do ścigania wszelkiej przemocy w życiu publicznym. Krytykował również powołanie specjalnych oddziałów policji przeznaczonych do zwalczania manifestacji, w tym specjalnie szkolonych do brutalnego pacyfikowania manifestacji opozycji na ulicach (Litwiński, 2018, s. 217).

Jako parlamentarzysta podkreślał także zachodzące zmiany w ustawodawstwie. Za pewien niedościgniony wzór uważał w tym względzie pierwsze lata niepodległości, które w jego opinii odznaczały się rozległą pracą ustawodawcza, realizującą podstawowe interesy państwa i jego obywateli. Ustawodawstwo w pierwszych latach 
niepodległości było gruntownie przemyślane, pomimo konieczności scalenia w szybkim tempie niepodległego państwa. Tym zaletom prawodawstwa pierwszych lat niepodległości przeciwstawiał praktykę legislacyjną rządów pomajowych. W jego ocenie wszelkie ustawy, czy nawet rozporządzenia wykonawcze, wydawano często w sposób nieprzemyślany, a konsekwencją takiego procedowania była konieczność ustawicznego nieomal zmieniania prawa. Według Strońskiego ulubionym trybem prac obozu pomajowego $\mathrm{w}$ ustawodawstwie było uzyskiwanie rozległych pełnomocnictw, a następnie przeniesienie pracy ustawodawczej parlamentu na dekretowe rozwiązania wydawane przez władze wykonawcze. Z czasem doszło do wynaturzenia, kiedy doraźnie stosowane wcześniej pełnomocnictwa zamieniły się w stałe nieomal urządzania ustawodawcze.

Podobnie uważał, że sądownictwo polskie przed zamachem majowym miało wysoki autorytet społeczny, broniony dodatkowo przez zagwarantowaną niezależność sędziów. Zwracał uwagę na politykę personalną rządów piłsudczykowskich, które w jego ocenie chciały zmienić ten stan rzeczy i wpłynąć na zmiany w wymiarze sprawiedliwości, głównie poprzez mianowanie na najwyższe stanowiska w sądownictwie tzw. „swoich ludzi”. Stroński podkreślał też, że niekiedy działo się to w sposób rażący, gdyż pomijano kolejność awansu wynikającą z kompetencji sędziów, a nie wahano się powoływać ludzi bezwzględnie lojalnych wobec obozu rządzącego. Wskazywał przy tym, że źródłem tego procederu było obsadzone przez piłsudczyków ministerstwo sprawiedliwości, które stało się sprawnym narzędziem wiodącym do zdominowania niezależnego wcześniej sądownictwa.

Ten stan rzeczy musiał doprowadzić do istotnej szkody w życiu państwowym, gdyż główną troską rządzących było utrzymanie się u władzy. W konsekwencji doszło do demoralizacji wielu urzędników państwowych. Zdaniem Strońskiego było to widoczne w różnych obszarach życia publicznego. Jednym z nich było szkolnictwo. Stroński piętnował różnorodne zaniedbania w tej dziedzinie - od szkolnictwa podstawowego po wyższe - i podporządkowanie go władzom centralnym z ograniczeniem autonomii uczelni. Krytykował zresztą nie tylko zmiany strukturalne (np. w postaci reform Janusza Jędrzejewicza), ale także zmiany programowe, które stopniowo implementowano do wszystkich szczebli szkolnictwa. W jego opinii 
błędem było wprowadzanie ideologii do nauczania szkolnego. Sięgał tu po kontrowersyjne porównania, pisząc o wychowaniu młodzieży:

Podobnie jak faszyzm chwytał w swoje kleszcze młodzież od dziecka w Ballila, a hitleryzm tworzył tzw. Hitlerjugend, podobnie zresztą jak bolszewizm od dziecka po swojemu urabiał duszę i umysły młodzieży, tak u nas postanowiono zastąpić niemal wszystkie dotychczasowe podstawy wychowania ideologią Piłsudskiego. (Stroński, 2007, s. 58) (Wójcik-Łagan, 2012).

Władza autorytarna to dla Strońskiego także poważne reperkusje w życiu gospodarczym. Zwracał uwagę na niekompetencję ludzi na wysokich stanowiskach. Jedynym kryterium były ich zasługi wobec obozu rządzącego, często byli to ludzie wywodzący się z wojska. Osoby takie albo otrzymywały w nagrodę "ttuste posady", albo dawały rękojmię całkowitego podporządkowania przełożonym. Awansowanie miernot kosztem sił fachowych musiało - zdaniem Strońskiego - prowadzić do problemów społecznych oraz gospodarczych. Początkowo nikt nie zwracał specjalnie uwagi na ten tryb awansów w życiu gospodarczym, gdyż zamach majowy trafił na względnie dobrą koniunkturę gospodarczą. Wszystkie konsekwencje tego sposobu administrowania gospodarką państwową nasiliły się, gdy do Polski ok. 1930 roku dotarł wielki kryzys gospodarczy i obnażył słabe strony administracji piłsudczykowskiej. Według Strońskiego obóz rządzący był zupełnie bezradny wobec skali zjawisk gospodarczych, a praprzyczyną tego stanu rzeczy była forma rządów promująca miernych, ale wiernych nowym przywódcom (Mierzwa, 2012, s. 490).

Krytyka Strońskiego uderzająca w autorytarne rządy sięgała dalej niż polityka czy gospodarka. Mocno akcentował on dokonujące się równoległe niszczenie szeroko rozumianego życia społecznego. W sytuacji, gdy kierując się pychą - stosunkowo nieliczna - grupa uznała się za właścicieli państwa, które rzekomo sami wywalczyli, musiało to doprowadzić do odsunięcia wartościowych jednostek. Nastąpiło zniechęcenie wielu obywateli do aktywnego udziału w życiu publicznym na poziomie samorządów terytorialnych czy nawet zawodowych. Stroński wskazywał, że niewielka grupa głosiła, iż ponosi wyłączną odpowiedzialność za całe państwo i nie zamierzała z nikim jej dzielić. Słuszne w jego ocenie hasło silnej władzy wykonawczej zostało tym samym skrajnie wypaczone. Wszelki samorząd wynikający z prawa 
publicznego, a więc gminny, miejski, gospodarczy, zawodowy, terytorialny, został w ten czy inny sposób (poprzez nominacje lub rozwiązania ustrojowe) bezwzględnie podporządkowany rządowi centralnemu. Podkreślał przy tym mocno, że zjawisko to było najbardziej widoczne w relacjach obozu rządzącego z samorządami największych miast w kraju, gdzie zwalczanie niezależności samorządu było rażące i dla wszystkich w kraju widoczne. Stroński cytował popularne w tym okresie powiedzenie oparte na grze słów: „nie istniał w Polsce samorząd, ale tylko sam rząd" (Stroński, 2007, s. 61).

Jako polityk chadecki zwracał uwagę także na poziom duchowy i obyczajowy ekipy rządzącej. Oceniając piłsudczyków pod tym względem, nie widział $u$ nich wielu zalet. Nie dostrzegali bowiem oni znaczenia wiary i generalnie religii $\mathrm{w}$ życiu narodu. Widział na szczytach władzy osoby niewierzące z pokiereszowanym życiem osobistym, co wówczas było także argumentem politycznym. Istotnie, jak wiemy, w gabinetach rządzących po maju 1926 roku zasiadało nieproporcjonalnie wielu ewangelików, bo zmiana wyznania pozwalała na formalne przeprowadzanie rozwodu i ponowny ożenek. Zdaniem Strońskiego byli oni źródłem zgorszenia wielu współobywateli, znających meandry ich życia osobistego, dalekie od ówczesnych norm obyczajowych (Piotrowski, 2009, s. 69). Dostrzegał także instrumentalne traktowanie Kościoła katolickiego. Piłsudczycy kierowali się w stosunku do niego pragmatyką polityczna, a nie postawą wynikającą z autentycznej wiary i przekonań. Pomajowe rządy charakteryzował poprawny stosunek do duchowieństwa tylko wtedy, gdy było im to potrzebne, natomiast konsekwentne zwalczanie tych, którzy odważali się autorytarną władzę skrytykować. Zdaniem Strońskiego zasadniczy błąd piłsudczyków polegał na lekceważeniu siły, jaką daje narodowi wiara i taktowanie jej jako zło konieczne, które po prostu nie sposób obalić od razu, a postępować należy ostrożnie i ograniczać wpływy kleru stopniowo w długim okresie sprawowania władzy. Czy istotnie piłsudczycy mieli takie intencje, czy też Stroński koniecznie chciał wystąpić w roli obrońcy ",tradycyjnych wartości", trudno to jednoznacznie przesądzić, bo nie sposób odtworzyć systemu wartości polityków prowadzących wówczas ten zajadły spór - także w warstwie celowego wykorzystania symboli religijnych. Na tym polu jednak Stroński miał pewną przewagę nad swymi adwersarzami i niewątpliwie był tu bardziej wiarygodny. 
Nie stronił też od trudniejszych dla siebie terenów polemiki. Na pewno taką areną sporów, w której miał mniejsze doświadczenie, była szeroko rozumiana obronność. Na tle innych nurtów politycznych trudno było piłsudczykom - wywodzącym się wszak z wojska - zarzucić niekompetencję w tym obszarze życia państwowego. Jednak Stroński się nie uląkł i tu także wskazywał na słabe strony rządów autorytarnych. Podkreślał, że rządzący uprawiali w tym zakresie propagandę sukcesu, tymczasem klęska wrześniowa obnażyła wieloletnie zaniedbania $\mathrm{w}$ obszarze wzmocnienia obrony państwa. Zdaniem publicysty wielu zdolnych generałów zostało po zamachu majowym odsuniętych, jak np. gen. Tadeusz Rozwadowski, gen. Włodzimierz Zagórski, a później także gen. Władysław Sikorski. W opinii Strońskiego - wyrażonej już po klęsce wrześniowej - obóz rządzący nie wydał żadnego wybitniejszego dowódcy. To nie wydaje się oceną sprawiedliwą w kontekście dokonań gen. Kazimierza Sosnkowskiego (Wojewódzki, 2009, s. 77). Krytycznie oceniając obóz pomajowy, publicysta wskazywał, że sam Piłsudski w dziedzinie wojskowości był po prostu samoukiem, jak wiemy znawcą powstania styczniowego, ale nie kształcił się $\mathrm{w}$ późniejszych latach i nie dotrzymywał kroku wielkim zmianom w zakresie organizacji armii zachodzącym wówczas na świecie. Był już schorowanym starszym panem, nierozumiejącym znaczenia nowoczesnych rodzajów sił zbrojnych, a system autorytarny umacniał jego pozycję i sprawiał, że wszelka krytyka przestarzałych założeń była w praktyce niemożliwa. Kontrolujący w szczegółach awanse w armii Marszałek był dla Strońskiego wodzem anachronicznym. Wyrażając taką opinię znał już jednak doświadczenia drugiej wojny światowej, które wszak zasadniczo zmieniły postrzeganie prowadzenia nowoczesnej wojny.

Najsilniej krytykował jednak sam ustrój państwa autorytarnego, który określał mianem dyktatury z ograniczoną odpowiedzialnością (Stroński, 2007, s. 63). Podkreślał, że Marszałek dysponował władzą rozstrzygająca, ale de facto nie brał formalnej odpowiedzialności. Rzadko pełnił funkcję szefa rządu, zadowalając się stanowiskiem ministra spraw wojskowych. Zdaniem Strońskiego było to charakterystyczne dla niego jako człowieka i polityka, bowiem i tak wszyscy w Polsce wiedzieli, że ostateczne rozstrzygnięcia we wszystkich dziedzinach należały do niego. Wszyscy rządzący z jego nadania odpowiadali przed Piłsudskim za swe poczynania, a jeśli wykazywali 
zbytnią samodzielność, bywali przez czujnego dyktatora odsuwani na boczny tor (Piotrowski, 1994, s. 113).

Granice dla autorytarnej formy rządów stanowiła Konstytucja, jednak bez specjalnego dbania o jej zapisy. Zdaniem Strońskiego rządy piłsudczyków formalnie funkcjonowały po zamachu na podstawie Konstytucji marcowej 1921 roku z istotnymi uzupełnieniami z roku 1926 (nowela sierpniowa), niemniej w praktyce nie troszczono się zbytnio o konstytucyjny stan prawny. Jego zdaniem rządzono $\mathrm{w}$ trybie nieomal ustawicznego gwałcenia czy naginania Konstytucji. Był to okres gry politycznej ze strony Piłsudskiego, wobec ciał ustawodawczych, które często były pomijane i pozbawiane możności działania. Zmianę przyniosło dopiero uchwalenie Konstytucji kwietniowej w 1935 roku, choć i tu trudno się dopatrywać szczególnego poszanowania dla jej zapisów. Kiedy po śmierci Piłsudskiego zaszła konieczność podziału władzy na nowo, wydano okólnik ustanawiający drugą osobą w państwie marszałka Edwarda Rydza-Śmigłego, choć Konstytucja nie przewidywała takiej godności.

Dla Strońskiego, który był wybitnym politykiem opozycji, papierkiem lakmusowym - niezwykle ważnym w ocenie tej formy rządów był jej stosunek do opozycji parlamentarnej. Tu argumentem rozstrzygającym stały się słynne wybory brzeskie i ich okoliczności. Stroński krytykował już wcześniej, przy wyborach w 1928 roku, rozliczne nieprawidłowości (np. zaangażowanie administracji po stronie BBWR). Jednak, jak podkreślał, Rubikon został przekroczony w połowie 1930 roku, kiedy to Marszałek dla stworzenia przychylnej sobie większości w parlamencie zdecydował się sięgnąć po terror w życiu publicznym. Tak bowiem oceniał Stroński uwięzienie przywódców stronnictw $\mathrm{w}$ twierdzy w Brześciu przed wyborami. Uczyniono to $\mathrm{z}$ pominięciem wszelkich dróg prawidłowego wymiaru sprawiedliwości, a do tego postępowano wobec nich w sposób hańbiący na zawsze obóz Piłsudskiego, stosując przemoc fizyczną wobec Hermana Liebermana czy poniżanie byłego premiera Wincentego Witosa (Witos, 1990, s. 341). Tego jako demokrata, przywiązany do wartości parlamentaryzmu, nie mógł żadną miarą zaakceptować. To była w jego ocenie zbrodnia wobec demokracji i wobec niepodległego państwa, której usprawiedliwić nie można. Autorytaryzm ujawnił swe prawdziwe oblicze, gdy został zagrożony w swych posadach utratą władzy i ewentualnym poniesieniem konsekwencji swych poczynań. 


\section{POLITYKA ZAGRANICZNA}

Zupełnie osobną dziedziną krytyki ówczesnych rządów autorytarnych była polityka zagraniczna. Stroński był frankofilem, który sojusz z Francją uważał za fundament polityki międzynarodowej odrodzonego państwa. W jego ocenie Polski nie było stać na jakiekolwiek eksperymenty w tej dziedzinie. Chciał umocnienia tego sojuszu, natomiast rządzącym po 1926 roku piłsudczykom często zarzucał jego celowe osłabianie. Z niepokojem obserwował narastający wśród rządzących sceptycyzm wobec solidności alianta, zresztą uzasadniony (Gmurczyk, 2003, s. 31). Tymczasem dla niego zbieżność prowadzonej polityki z międzynarodowymi celami Paryża była po prostu podstawą polskiej racji stanu.

Zdaniem Strońskiego gwałtowne pogorszenie w dziedzinie polskiej polityki zagranicznej nastąpiło pod koniec 1932 roku po objęciu ministerstwa spraw zagranicznych przez Józefa Becka. Wcześniej dostrzegał zabiegi ministra Augusta Zaleskiego, który wprawdzie raczej stawiał na Anglosasów, ale jednak dbał też o utrzymanie relatywnie dobrych stosunków z Paryżem. Zdaniem Strońskiego miał on nawet pewne sukcesy, jak np. wybranie Polski na kolejną trzyletnią kadencję do Rady Ligi Narodów. Jednak piłsudczycy nie mogli tolerować na czele MSZ człowieka, który nie wywodził się ze środowiska legionowego. Nie był też do końca dyspozycyjny wobec Marszałka (Beck, 1987, s. 39), stąd właśnie w osobistej niezależności ministra upatrywał przyczyny roszady na stanowisku szefa dyplomacji. W 1932 roku dotychczasowy podsekretarz stanu w MSZ J. Beck został szefem tego resortu. Zdaniem Strońskiego był to poważny błąd, bo na miejsce polityka doświadczonego i wytrawnego dyplomaty awansowano zawodowego oficera o mentalności wykonawcy zleconych zadań.

Stroński podkreślał, że to natura rządów autorytarnych - nie znosząca wybitniejszych i samodzielnych jednostek - spowodowała konieczność tej zmiany personalnej. Oczywiście dziś możemy dywagować, czy istotnie minister Zaleski był wybitniejszą osobowością niż jego następca, niemniej argument o jego doświadczeniu dyplomatycznym wydaje się trafny.

Zasadniczym problemem poruszanym przez Strońskiego przy okazji tej zmiany nie były jednak kwestie personalne, a raczej ewidentne próby korekty czy modyfikacji dotychczasowych relacji w polityce 
międzynarodowej. Postrzegał je jako zagrożenie dla bezpieczeństwa państwa i określał jako poszukiwania nowych dróg uprawiania dyplomacji, które prowadziły Polskę na manowce. Stroński jako realista - w swoim mniemaniu trafnie oceniający rzeczywisty potencjał gospodarczy i militarny kraju - uważał mrzonki o mocarstwowym statusie Polski za niebezpieczne, a poszukiwanie ich potwierdzenia poprzez awanturnicze decyzje za skrajnie nieodpowiedzialne.

Po latach wspominał krytycznie próby nawiązania poprawnych stosunków z Trzecią Rzeszą. Miał tu silny argument, bowiem przypominał, że jako poseł, debatujący wówczas w sejmie tuż po deklaracji o niestosowaniu przemocy z 26 stycznia 1934 roku, wskazywał zarówno pozytywne, jak i słabe strony treści tej deklaracji. Podkreślał wówczas, że główne niebezpieczeństwo tego układu nie tkwiło w jego treści (która była dla większości polskich polityków do zaakceptowania), ale raczej w idącej za tym układem próbie poróżnienia Polski z innymi państwami. Stroński niczym Kasandra wskazywał także sprzeczne $z$ duchem deklaracji dążenia władz niemieckich wyraźnie skierowane przeciw Polsce, jak choćby polityka Trzeciej Rzeszy wobec mniejszości polskiej na jej terytorium.

W swej publicystyce - szczególnie w latach drugiej wojny światowej, gdy na uchodźctwie poważnie planowano federację z Czechosłowacją po wojnie - Stroński wielokrotnie powracał do problemu stosunków z południowym sąsiadem. Wskazywał na fakt, że nieprzypadkowo po 26 stycznia 1934 roku w mediach kontrolowanych przez autorytarną władzę w Polsce pojawia się nieomal nieprzerwana nagonka na Czechów pod hasłem krzywdy doznanej w 1919 roku na Śląsku Cieszyńskim. Nagonkę tę prowadziła w jego ocenie głównie ówczesna polska dyplomacja i pisma prorządowe bądź do rządu zbliżone. Nieprzypadkowo urządzano wówczas demonstracje skierowane przeciwko Czechom. Warto przy tym zaznaczyć, iż Stroński był chyba zbytnim optymista, pisząc że nasze słuszne żądania Czesi skłonni byli rozpatrzyć na podstawie układu Benesz - Skrzyński z roku1925, ustalającego precyzyjnie kwestię wzajemnego postępowania wobec mniejszości narodowych. Jego zdaniem była tu możliwość kompromisu i porozumienia. (Stroński, 2007, s. 73). Tymczasem autorytarna władza, nie licząc się z głosami opinii publicznej, wybrała rozwiązania "mocarstwowe”. Polityka porozumienia nie była po myśli Piłsudskiego i ministra Becka, którzy 
stawiali na brutalne postępowanie, zgodne z ówczesnymi dążeniami Niemiec, które osaczyły Czechosłowację. Stroński był zdania, że to działanie - sprzeczne z polską racją stanu - nie byłoby możliwe, gdyby forma rządów w Polsce była inna. Gdyby brano pod uwagę głos opinii publicznej i decyzję większości parlamentarnej, wybraną w uczciwy sposób, bez terroru brzeskiego w 1930 roku. Zatem winę za udział Polski w rozbiorze Czechosłowacji (obok Niemiec) przypisywał wyraźnie niekontrolowanym demokratycznie rządom autorytarnym.

Zresztą katalog „win” tej władzy w dziedzinie polityki zagranicznej był jego zdaniem o wiele szerszy. Przywoływał np. sprawę stosunków z Wolnym Miastem Gdańskiem. Stroński twierdził, że zasadnicza postawa polskiej dyplomacji, aby nie mieszać się do wewnętrznych spraw Gdańska, a jedynie pilnować polskich praw w tym mieście, była głęboko błędna. W jego ocenie wyrażonej post factum każde pogwałcenie konstytucji gdańskiej i wprowadzenie tam ducha nazistowskiego oraz haseł łączności z Rzeszą już naruszało nasze prawa, a ponieważ obie te sprawy były ze sobą splecione, ich rozdzielenie od siebie było niemożliwe.

Stroński krytykował również, nie zawsze obiektywnie, stosunek polskich władz wobec forsowanego przez Paryż tzw. paktu wschodniego (Gregorowicz, 2013, s. 133). Twierdził, że bezpodstawnie wmawiano społeczeństwu, iż to rozwiązanie jest dla Polski nie do przyjęcia, bo rzekomo musielibyśmy zezwolić Sowietom na przemarsz przez nasze terytorium. Jego zdaniem była to nieprawda, gdyż w projekcie tego paktu nie było mowy o obowiązku zezwolenia na przemarsz obcych wojsk. Podkreślał też, że idea paktu wschodniego, obejmującego kraje od Francji do Rosji, w tym Niemcy, Czechosłowację, Polskę, kraje bałtyckie, miała zapewnić pokój. Koncepcja ta, wobec odmowy Niemiec, najprawdopodobniej dotyczyłaby pozostałych wymienionych krajów, wiążąc Berlinowi ręce ze wszystkich stron. Stroński uważał, że pakt ten ujęty w zarysie w czerwcu 1934 roku, był nie na rękę piłsudczykom, gdy się okazało, że w istocie jest wymierzony przeciw Niemcom. Zatem w jego ocenie autorytarna władza, nie licząc się z nikim i niczym, odrzuciła propozycję paktu bezpieczeństwa (Eden, 1970, s. 131).

Zawiniła tu m.in. irracjonalna po części wrogość wobec Francji, traktującej Warszawę jako swego protegowanego, a nie samodzielny 
podmiot polityczny. Stroński dawał do zrozumienia, że kierując się urażoną dumą i przesadnym wyobrażeniem na swój temat, władza autorytarna w Polsce popełniała zasadnicze błędy w polityce zagranicznej. Przypominał okoliczności wizyty ministra spraw zagranicznych Francji w 1934 roku, jak choćby niedopuszczenie życzliwej Francji publiczności na dworzec i utrudnianie mu kontaktów na miejscu. Stroński - ewidentnie nieco przeczulony na swym punkcie - przypominał, że będąc wówczas jako poseł członkiem Komisji Zagranicznej Sejmu nie otrzymał zaproszenia na przyjęcie $\mathrm{w}$ ambasadzie francuskiej. Decyzję tę podjęły władze polskie, rozstrzygając iż na przyjęciu tym mogą być tylko te osoby, które były uprzednio na przyjęciu u ministra Becka, zatem w praktyce jedynie ludzie obozu rządzącego. Władza autorytarna nie dopuszczała do dyskusji na temat polskiej polityki zagranicznej przedstawicieli opozycji.

Oceniając całościowo prace dyplomacji stworzonej przez piłsudczyków, Stroński był mocno krytyczny. Podkreślał elementarny brak jej skuteczności. Krytykował podstawową myśl jej twórców, zmierzających do podtrzymania i umocnienie suwerenności Polski na arenie międzynarodowej. Jego zdaniem więcej w tym było taniej chełpliwości niż treści. „Wyzwolenie się" od rzekomej zależności od polityki francuskiej nie było tego warte, bo też dominacja francuska nie była w żaden sposób uciążliwa, ale wynikała po prostu z elementarnej asymetrii potencjałów obu państw. Owszem Stroński dostrzegał próbę sojuszu z Anglosasami, ale nie widział ich zainteresowania aż do 1939 roku. W jego ocenie autorytarna władza w Polsce karmiła się iluzjami. W praktyce bowiem niezależność polityki polskiej nie była przed majem 1926 ani trochę mniejsza niż po maju 1926 roku, a szermowanie tym hasłem i zarzutem wobec opozycji było bezzasadne.

\section{ZAKOŃCZENIE}

Na tym tle widział Stroński przyczyny klęski wrześniowej 1939 roku, która obnażyła całą słabość państwa źle rządzonego przez system rządów autorytarnych. W tym ujęciu wybuch wojny nie był jednostkowym zdarzeniem, które nastąpiło niezależnie od sytuacji politycznej w Drugiej Rzeczypospolitej. Był raczej smutną konsekwencją wcześniejszych zaniedbań i błędów, przy czym zaznaczał: 
Poglądy, które tu przedstawiłem, wypowiadałem stale, występując przeciw polityce pomajowej, więc nie są to tylko i dopiero poglądy post factum. W ogóle ostrzeżeń było sporo. Ale uparcie lekceważono wszelkie zdania odmienne (Stroński, 2007, s. 89).

Wybuch wojny był momentem przełomowym, który umożliwił odsunięcie od władzy zbankrutowanych polityków usiłujących odcinać kupony od autorytetu nieżyjącego już Marszałka. Jego pamięć z kolei obciążał fakt stworzenia systemu rządów autorytarnych, które doprowadziły do osłabienia państwa tak w wymiarze wewnętrznym, jak i zewnętrznym. Stroński dostrzegał zarówno prężność polityki Niemiec, jak i Rosji Sowieckiej wobec słabo zarządzanej Polski. Niemniej nie uważał nigdy naśladowania systemów totalitarnych za lekarstwo dla naszego kraju. W jego ocenie rozwiązania demokratyczne, stwarzające możliwość działania dla ogółu obywateli i wiążące ich z państwem, były wówczas optymalne. Tymczasem narzucone siłą rządy autorytarne doprowadziły do ich odrzucenia we wszystkich niemal dziedzinach życia publicznego - od życia gospodarczego, w znacznej mierze kreowanego przez rząd, dalej edukacji, poprzez sądownictwo aż do obrony państwa i błędnie prowadzonej polityki międzynarodowej. Widział u piłsudczyków, poszukujących dla Polski partnerów na arenie międzynarodowej, fascynację siła, natomiast relatywnie słabszą skłonność do współpracy z partnerami nieco słabszymi, ale rządzonymi w sposób demokratyczny, jak Francja czy Czechosłowacja. Wszystkie te elementy - w jego ocenie - doprowadziły do katastrofy i upadku z takim trudem odbudowanego państwa.

Jak widzimy, krytyka rządów autorytarnych w Polsce przed wrześniem 1939 roku na łamach pism Stanisława Strońskiego miała charakter kompleksowy i podnosiła cały szereg argumentów przeciw tej formie władzy. Niektóre z nich, jak choćby przejęcie rządów siłą poprzez zamach zbrojny, są charakterystyczne dla omawianej epoki. Inne mogą niekiedy być postrzegane jako zjawiska wyraźnie ponadczasowe, charakterystyczne dla tej formy rządów, przykładowo konflikt na linii władza centralna - samorządy dużych miast, reforma edukacji (strukturalna i programowa) oraz sądownictwa w kierunku jego „zdyscyplinowania”, obsadzanie spółek kontrolowanych przez państwo reprezentantami władzy autorytarnej, próby podporządkowania władzy wykonawczej większości mediów itd. Trudno dziś jednoznacznie rozsądzić, które z tych elementów występują dziś 
w Trzeciej Rzeczypospolitej i czy to podobieństwo ma charakter jedynie przypadkowy? Każdy z czytelników musi sam sobie odpowiedzieć na te pytania. Na pewno istnieją ogólne prawidłowości charakteryzujące rządy oparte na autorytecie jednostki, które występują wówczas jaskrawiej niż przy zwykłej w demokracji wymianie elit rządzących. Czy i na ile ma to miejsce w Polsce także dziś? Jedno, co wiemy na pewno, to, że każdy z tych problemów wymagałby osobnego szczegółowego opracowania, a przy tym podobno nie można wejść dwa razy do tej samej rzeki... (?)

\section{BiBLIOGRAFIA}

Beck, J. (1987). Ostatni raport. Warszawa: Państwowy Instytut Wydawniczy.

Eden, A. (1970). Pamiętniki 1923-1938. Warszawa: Instytut Wydawniczy PAX.

Faryś, J. (1990). Stanistaw Stroński, Biografia polityczna do 1939 roku. Szczecin: Wydawnictwo Uniwersyteckie.

Gmurczyk-Wrońska, M. (2003). Polska - niepotrzebny aliant Francji. Warszawa: Wydawnictwo Neriton.

Gregorowicz, S. (2013). Francusko-sowiecka gra polityczna z dyplomacją polską. Pakt Wschodni 1934-1935. W: M. Kornad (red.), Ład wersalsko-ryski w Europie Środkowo-Wschodniej 1921-1939. Kraków: Wydawnictwo Lettra-Graphic.

Litwiński, R. (2018). Kordian Józef Zamorski, "granatowy" generał. Lublin: Wydawnictwo UMCS.

Mierzwa, J. (2012). Starostowie Polski Międzywojennej, portret zbiorowy. Kraków: Wydawnictwo UJ.

Piotrowski, J. (1994). Aleksander Prystor 1874-1941. Wrocław: Wydawnictwo UWr.

Piotrowski, J. (2004), Dzienniki czynności prezydenta RP Władysława Raczkiewicza 1939-1947, t. I. Wrocław: Wydawnictwo UWr.

Piotrowski, J. (2009). Generał Stefan Hubicki, żotnierz, polityk, lekarz 18771955. Wrocław: Wydawnictwo GAJT.

Rojek, W. (1994). Protokoły z posiedzeń Rady Ministrów Rzeczypospolitej Polskiej (październik 1939 - czerwiec 1940), oprac., t. I. Kraków: Wydawnictwo Secesja.

Rutkowski, T.P. (2000). Stanisław Kot 1885-1975, Biografia polityczna. Warszawa: Wydawnictw DiG. 
Sioma, M. (2005). Stawoj Felicjan Składkowski 1885-1962, żotnierz i polityk. Lublin: Wydawnictwo UMCS.

Stroński, S. (2007). Polityka rządu polskiego na uchodźstwie w latach 19391942, t. I. Nowy Sącz: Wydawnictwo Goldruk.

Witos, W. (1990). Dzieła wybrane, Moje wspomnienia, t. II. Warszawa: Wydawnictwo LSW.

Wojewódzki, I. (2009). Kazimierz Sosnkowski, Ksiażę niezłomny czy Hamlet w mundurze?. Warszawa: Wydawnictwo NCK.

Wójcik-Łagan, H. (2012). Kult bohatera narodowego, Józef Pitsudski w szkolnej edukacji historycznej w latach trzydziestych XX wieku. Kielce: Wydawnictwo UJK.

\section{Copyright and License}

This article is published under the terms of the Creative Commons Attribution - NoDerivs (CC BY- ND 4.0) License http://creativecommons.org/licenses/by-nd/4.0/ 